\title{
The Monstrous-Feminine in Contemporary Japanese Popular Culture
}

By Raechel Dumas. Cham, Switzerland: Palgrave Macmillan, 2018. ix, 217 pp. \$84.99.

\section{Reviewed by Andrew Campana}

Sadako - the vengeful ghost girl in the Ring horror franchise who resides both at the bottom of a well and inside a cursed videotape - cannot be contained. She has made the leap from novel to film, manga to video game, radio play to urban legend, cosplay inspiration to theme park attraction, and from Japan to truly global popularity. In The Monstrous-Feminine in Contemporary Japanese Popular Culture, Raechel Dumas takes on Sadako and many other figures like her in all their complexity. Dumas combines close readings of their cross-media proliferations with a rich array of theoretical approaches, as well a valuable account of the societal shifts in Japan from the late 1980s to the present from which their emergence is inextricable.

Chapter 1, "Open Wounds," begins with a substantial introduction to the concept of "the monstrous-feminine," a term coined by Barbara Creed in her 1993 book of the same name. It refers to the configurations of femininity and horror that have come to be a worldwide trope, one that is strikingly ubiquitous in Japan. "Scenes invoking menstrual leakage, grotesque transformation, monstrous impregnation, and gruesome birth saturate the Japanese pop cultural imagination," says Dumas, "as do homicidal schoolgirls, murderous maternal figures, vengeful female ghosts, apocalyptic priestesses, and other monstrous-feminine tropes that threaten the integrity of the patriarchal sociocultural order" (7).

The core content chapters all have a similar shape, examining about two franchises or works - usually in the same medium - that highlight an aspect of the monstrous-feminine in Japanese pop culture. Dumas always does this with an eye towards an essential ambivalence at the heart of each example: in the majority of the works under consideration, each particular manifestation of the monstrous-feminine is deliberately horrifying in how it embodies patriarchal anxieties about societal breakdown, particularly those related to the role of women and girls amid vast cultural change. At the same time, even if they are somehow thwarted or tamed at the end of 
132 Japanese Language and Literature

the narrative, the main draw of these feminine monsters is in their spectacular flaunting of societal and bodily norms, behaviors, hierarchies, and structures. In this way, the monstrous-feminine is an undeniable source of pleasure and potential resistance.

Chapter 2, "The Girls That Never End," looks at the use of the trope of the infinitely multiplying horror girl in two cross-media franchises: Tomie, originally a manga series by Itō Junji that started in the late 1980s, and the aforementioned Ring, which began as a 1991 novel by Suzuki Kōji. At a time of pronounced fear surrounding the unruly sexuality of young women and girls (shöjo) and their perceived obsession with material culture, Tomie and Ring's Sadako are shojo with the ability to endlessly replicate themselves: Tomie from any fragment of her body, Sadako through a virally-spreading cursed videotape. Dumas argues that Tomie and Sadako are exemplars not just of terrifying, unproductive reproduction, but also of the pleasures of radical differentiation, infinite potentiality, and resistance to hegemonic modes of subjectification imposed upon femininity.

Chapter 3, "Xenogenesis," turns to science fiction, focusing on two novels_-Sena Hideaki's Parasite Eve from 1995, and Asamatsu Ken's Queen of K'n-Yan from 1994. Both are centered around the trope of "monstrous motherhood," and were released at a time-after the burst of Japan's economic bubble —in which there was an intense sense of crisis surrounding maternity amid a restructuring of labor (57-58). The titular figure of Parasite Eve is an embodiment of mitochondrial DNA, who seeks to infect the genetic code of all of humanity. The Queen of K'nYan-a tentacled monster of an ancient subterranean race experimentally resurrected at the site of a 1940s Japanese prison camp in Manchukuohorrifies the reader with scenes of grotesque mutation and the subsuming of other bodies into hers. In a virtuosic reading drawing on Derrida's notion of "hauntology," Dumas argues that the Queen becomes a "specter that speaks... to the violence of historical erasure" and the denial of wartime culpability, at a moment of increased nationalism in 1990s Japan (84).

Chapter 4, "Faces of Horror, Dances of Death," analyzes Shiraishi Kōji's 2007 film The Slit-Mouthed Woman-based on an astonishingly enduring urban legend with roots in 1970s Japan - as well as the first few films of Shimizu Takashi's Ju-On franchise. Both are narratives of horror in the space of the home, centered around incidents of domestic violence: mothers against their children in The Slit-Mouthed Woman, and a husband 
killing his wife in Ju-On. The titular Slit-Mouthed Woman and the vengeful ghost Kayako of $\mathrm{Ju}$-On can certainly be read as manifestations of fears surrounding the dissolution of conventional family units. But, as Dumas argues, the experience of watching these films is also one of the visceral pleasure of encountering their excessive, monstrous-feminine embodiment: the reveal of an impossibly wide, cut-open mouth behind a surgical mask, and the radical butoh-inspired dance-like movements that make Kayako such a powerful presence.

Chapter 5, "Corrupted Innocence, Sacred Violence, and Gynoid Becomings," takes on the medium of the video game, examining the configurations of violence, technology, and the body in three game franchises that feature feminine horrors and apocalyptic cult practices: Silent Hill, Fatal Frame, and Siren. These games shift the location of violence from the private to the public, in the wake of high-profile incidents like the Tokyo subway sarin gas attacks in 1995, and the "Shōnen A" child murders in Kobe in 1997. While they have a conservative viewpoint at the level of narrative - in which the solution to the horror tends to be a "restoration of paternal authority"-Dumas argues that the experience of the games cannot be contained by this framework (134). The monstrous-feminine proves key to creating a subversive yet pleasurable field of play, in which control is constantly disrupted and the boundaries between bodies and technology are ever-shifting.

Chapter 6, "Disobedient Bodies, Monstrous Affinities," is a close look at a single 2008 novel by Kirino Natsuo, The Goddess Chronicle (the only work by a female creator highlighted in this book). In the novel, a girl takes the role of a "priestess of darkness" on a small island with Shintōesque beliefs, simultaneously powerful and excluded due to her "female defilement"; after her murder, the plot eventually takes her to the Realm of the Dead, in which the creation myths of the Kojiki are re-spun from a woman-centric perspective. Dumas examines the role of boseiai (maternal love) in a variety of Japanese feminist writings, and how The Goddess Chronicle reframes maternity not as a biological or political imperative (from the perspective of Japan's declining birth rates), but as a "metaphorical and profoundly ethical paradigm" in which the monstrousfeminine points towards new kinds of vulnerability and connection, ones that resist the "unsustainable expectations placed on Japanese women" (201).

Finally, in the concluding Chapter 7—“The End?"-Dumas reiterates the importance of looking at popular culture in a way that resists easy 
134 | Japanese Language and Literature

narratives about its tendency to reinforce societal norms, instead of doing justice to the ways in which it embraces multiplicity, ambiguity, and openness to other ways of being.

The Monstrous-Feminine in Contemporary Japanese Popular Culture is a delight to read and will be an invaluable tool for those who will be teaching any of the materials under consideration. While the sheer number of works, theorists, and analyses present in the text can sometimes verge on the overwhelming, Dumas's steady hand and clear prose ensure thatlike the monstrous-feminine itself - that excessiveness itself is a source of pleasure. Particularly refreshing is her decision to always acknowledge how each work contains within itself oppressive tropes and sites of resistance; misogynistic assumptions and feminist "lines of flight" away from prescribed modes of being. This is not due to any unsatisfying "both sides"-inflected thinking. It rather comes from the laudable goal to do justice to the complexities of the works under consideration. This means their ambivalences are highlighted rather than smoothed over into common narratives of pop cultural creations being uncomplicatedly "conservative" or "progressive." For so many of these materials, it is undeniable at the level of plot that the feminine itself is made monstrous in a way that is often only resolved by masculine intervention and the restoration of patriarchal order. At the same time, there is an immense power to Tomie's resilient multiplications, Sadako's virality, and Kayako's dancerly embodiment that exceeds the narratives that contain them, and point towards other modes of feminist possibility and analysis, ones that Dumas is able to capture.

This monograph is especially intriguing as a work of feminist media studies - as appropriate to the massive franchises under consideration, Dumas engages actively with novels, manga, films, and games. Some of the most compelling moments in the book come from her dealing with questions of form and technology and the specificities of the media under consideration: Tomie's relationship to manga panels and the medium of photography; the way the camerawork of The Slit-Mouthed Woman demarcates contested domestic realms; or the disruptiveness of the "sightjacking" mechanics in Siren that allow the player to take on the perspective of other characters and monsters. The only medium which does not receive the same treatment is literature - a consideration of the novel or the short story as medium and how its production, reception, and circulation relate to the monstrous-feminine would have been welcome. 
Dumas's fluency with different theoretical frameworks and ability to incorporate them clearly and effectively is a major asset. Using for the most part a combination of feminist philosophy, psychoanalysis, and media theory, she not only draws out aspects of the pop cultural works under consideration that would have been difficult to articulate otherwise, but also uses the works themselves to weave together and expand upon those concepts. Along with her drawing upon figures like Kristeva, Deleuze, and Derrida, Dumas's use of the lesser-known radical feminist psychoanalytic theorist and artist Bracha Ettinger-especially her concept of the "matrixial borderspace"-is particularly intriguing and extremely well-suited to the materials at hand.

Disability, however, is not mentioned in the book as a theme or category of difference, though there are several points where its incorporation would have added a significant facet to Dumas's analyses. Just about every work under consideration features monstrous-feminine figures who are not just gendered but also presented as disabled - blind, deformed, mad, and so on - and, indeed, the idea of the "monstrous" itself has historically been inextricable from the societal forces that mark some bodies as "normal" and others as "abnormal." While the theoretical framework of the book is among the most robust of any recent work in the field of Japan studies, incorporating some insights from critical disability studies would have enriched Dumas's explorations of the generative and affirmative aspects of non-normative embodiment.

While in previous work Dumas has taken the opportunity to introduce English-speaking readers to unusual and overlooked voices in Japanese literature, her decision here to feature only primary materials which are available in English translation works well for the monograph's aim, which is less of a survey of the monstrous-feminine trope than it is a series of analyses of its different facets. That decision does not apply, however, to secondary sources: one welcome aspect that differentiates this book from most other English-language works on similar materials is its extensive incorporation in its argumentation of contemporary Japanese thought from a variety of fields. Some of these thinkers' works - like the feminist writings of Ueno Chizuko and the media theory of Azuma Hiroki and Ötsuka Eiji - have been previously translated and are more familiar in the English-speaking world. Others, however, are central figures in several disciplines in Japan whose work has been translated very little or not at all, and Dumas's succinct introductions to key arguments by feminist critics like Kotani Mari and Ohinata Masami, film critics like Fukuda 
136 | Japanese Language and Literature

Asako, philosophers like Asada Akira, and sociologists like Miyadai Shinji, Makino Tomokazu, and Kurita Nobuyoshi, are a definite boon to the field of Japan studies.

Much like Sadako's cursed videotape in the Ring franchise, my immediate reaction upon finishing The Monstrous-Feminine in Contemporary Japanese Popular Culture was to share it with everyone I knew, as the most exciting scholarly monograph on contemporary Japanese horror to date.

\section{Danwa to Purofishienshĩ: Sono shin no sugata no tankyū to kyōiku jissen o mezashite (Discourse and Proficiency: Aiming for Pursuit of Truth and Educational Practice) 談話とプロフィシ エンシー その真の姿の探求と教育実践をめざして}

Edited by Osamu Kamada, Kazuko Shimada, and Ryoichi

Tsutsumi. Tokyo: Bonjinsha, 2015. iv, 238 pp. ¥2,600.

\section{Reviewed by}

Yumiko Kawanishi

Danwa to Purofishienshī: Sono shin no sugata no tankyū to kyōiku jissen o mezashite (hereafter Discourse and Proficiency) aims to provide crucial insights about actual language use in Japanese and instill the concept of discourse in Japanese language education. Kamada presents the definition of proficiency in the ACTFL OPI Tester Training Manual (Swender and Vicars 2012: 2) as "a degree" of "functional language ability - the ability to use a foreign language effectively and appropriately in real life setting." He defines discourse as any linguistic activity that occurs in context and suggests that shedding light on discourse is an important step towards improving learners' proficiency in Japanese language education. Throughout the whole volume, various teaching ideas are provided for actual classroom instruction. The entire book is written in Japanese.

Discourse and Proficiency consists of three main parts. Part I ("New Perspectives on Discourse") contains three chapters; each one reminds readers that discourse in real life is dynamic and complicated by showing how linguistic expressions and communicative behavior such as filler, discourse markers, and disfluency contribute to successful 